\title{
Religion and Ethic Values in Anecdote Based Stories of Omer Seyfettin
}

\section{Hatice FIRAT ${ }^{1}$}

\section{Summary}

Omer Seyfettin is one of the names of demonstrating and leading the development Turkish Literature story first of its kind, is well be an observer, writing technical know very well and in line with this successful event stories to draft. The writer, consider the art as a tool to serve society, therefore the public language / speech using which want to tell the public in the works is a set of facts. Thus, in Turkish literature, the type of story that connects with people has also gained importance as a writer.

One of the important features of Ömer Seyfettin is made stories which listened public narrative in childhood and teenage years and so many stories of Ömer Seyfettin has benefited from the resources of folk literature. Omer Seyfettin took up this type of in his works problems of deeply affecting to people, and showing the troubles has addressed arise in particular in accordance with tradition and religion in society.

\section{PURPOSE}

As noted in Turkish curriculum, in Turkish course the literary texts are important tools in the of values education. In the study important names of Turkish literature Ömer Seyfettin's stories was chosen as the subject of study of the source area. Works, are analyzed in line the similarities between the plot and the people. The study is aimed outstanding and the issue of disclosure author's opinion on the religion and moral values are addressed in the stories. In addition, purpose of the study can benefit from data obtained the texts of reveals the story of Ömer Seyfettin and other authors through the Turkish courses to students in order to add value.

\section{METHODS}

In the study, "document review" method was used. Document analysis, containing investigation of information about cases targeted analysis includes written materials. In addition "content analysis" that be brought together and arranged in a manner understandable to a method of helping to interpret certain concepts and themes similar to each other within the framework of data has been used for to data analysis.

\section{RESULTS AND DISCUSSION}

In the study were examined three stories of Ömer Seyfettin which described in article taken from the source known to the public. Omer Seyfettin is a writer of often read by children as well as adults. Topics a great extent has addressed the wounds and shortcomings to folk literature and folk stories from the field side of the society. Ömer Seyfettin has tried to give moral lessons benefiting humor through society by these issues. In the basis of three stories of Ömer Seyfettin's "Külah, Çakmak, Rüşvet" are rooted in the confidence of society of from his devotion to religion and religious people. The author is address in his works exploitation of religion through the religious-looking people and this regards his works:

1. Lie to people deceive with trick / game / lie

2. Obtain an unfair advantage because of greed and

\footnotetext{
${ }^{1}$ Assist. Prof., Muğla Sıtkı Koçman University, Faculty of Education, haticefirat@mu.edu.tr
} 
3. This gain as a means of benefiting from bribery or theft points were set upon. Therefore, the authors, is criticized using religion in accordance with the interests of the people with lies and deceit to trick, greed and theft / bribery. In contrast in his works, values as accuracy and honesty, satiated, solidarity, sharing, not being selfish are praised.

Terms of values education in the educational process is one of the outstanding lesson is "Turkish". The overall objective of Turkish curriculum materials, especially in the ninth and eleventh national, spiritual, universal values to students, introducing students to ensure that the values and practices of the binding is expressed as one of the main objectives. As for achieving these goals belong to Turkish and international literary culture and the arts as basic tools to be used are specified. According to data of study are understood that the authors of the works can be used for Turkish lessons, especially in education as a means to add value to the children. From this point, said that in the Turkish literature stories in the field of the most important name Ömer Seyfettin and other writers stories if selected carefully examined will serve the purpose tools can Turkish lessons valorization. 